\title{
NOVAS VOZES... NOVOS DIÁLOGOS
}

Nessa quinta edição damos continuidade aos processos de rememoração do CAp-UERJ trazendo, na seção entrevista, as vozes do Departamento de Ensino Fundamental, suas memórias, histórias e trajetórias.

Os artigos que compõem essa edição nos permitem dialogar sobre a temática de gênero e emancipação feminina, de autoria de Tereza Lopes Albuquerque; da comunicação e educação com o impacto das mídias na sociedade, de autoria de Adelaide Rocha de La Torre Chao e Alessandra Silva. Além desses, a articulação entre currículo e tecnologia chega a essa edição por duas abordagens: a primeira, de autoria de Ana Paula Pereira Marques de Carvalho, discutindo as novas possibilidades do trabalho em sala de aula com o uso das tecnologias e, ainda nesse campo, os desafios e contradições na produção cultural do currículo, com Roberta Sales Lacê Rosário. Larissa Marques Pires e Lucinéia Alves apresentam uma abordagem do ensino de ciências com os conceitos de ecologia e evolução. E encerramos essa seção com as reflexões sobre o cotidiano escolar e sua complexidade, de autoria de Maria Cláudia Reis.

A resenha desta edição nos permite o diálogo com a produção portuguesa de Rosanna Barros, que em "As políticas educativas para o sector de Educação de Adultos em Portugal: as novas instituições e processos educativos emergentes entre 1996-2006", permite-nos refletir sobre a educação e a formação de adultos em Portugal.

Boa leitura!

Andrea da Paixão Fernandes

Editora Geral 